Sains Malaysiana 48(8)(2019): 1721-1728

http://dx.doi.org/10.17576/jsm-2019-4808-18

\title{
Effects of Melamine and Cyanuric Acid on Renal Function and Structure in Rats
}

(Kesan Melamina dan Asid Sianurik kepada Fungsi dan Struktur Ginjal pada Tikus)

\author{
SARANYA PEERAKIETKHAJORN*, NAWIYA HUIPAO \& SIRIPHUN HIRANYACHATTADA
}

\begin{abstract}
Melamine has been used to increase the amount of measurable nitrogen which is a component of protein. The renal toxicity of melamine has been reported in infants and animals that consumed a mixture of melamine in their food products. This study aimed to investigate the effects of melamine on rat renal function using clearance and histological techniques. Animals were divided into 3 groups: vehicle control, $400 \mathrm{mg} / \mathrm{kg}$ melamine and mixture of $400 \mathrm{mg} / \mathrm{kg}$ melamine and 400 $\mathrm{mg} / \mathrm{kg}$ cyanuric acid (p.o., daily for three days). The results showed that blood urea nitrogen level significantly increased in the rats treated with the mixture of melamine and cyanuric acid. The urine flow rate, glomerular filtration rate, renal plasma flow and urinary sodium and potassium excretion rate significantly decreased when compared to vehicle control. These results suggested both glomeruli and renal tubules of rats treated with mixture of melamine and cyanuric acid were damaged. Histological study also confirmed these findings and showed significant glomerular atrophy and dilated renal tubules. Numerous clear brownish-yellow crystals were also found in the distal tubule, collecting tubule and papillary duct. However, rats solely treated with melamine showed no significant difference in renal function or structures.
\end{abstract}

Keywords: Cyanuric acid; histology; melamine; rat; renal clearance

ABSTRAK

Melamina telah digunakan untuk meningkatkan jumlah nitrogen yang boleh diukur yang merupakan komponen protein. Ketoksikan ginjal daripada melamina telah dikesan pada bayi dan binatang yang mengambil campuran melamina dalam produk makanan mereka. Kajian ini bertujuan untuk mengkaji kesan melamina pada fungsi buah pinggang tikus menggunakan teknik pembersihan dan histologi. Haiwan kajian dibahagikan kepada 3 kumpulan: Kawalan pengangkut, melamina $400 \mathrm{mg} / \mathrm{kg}$ serta campuran melamina $400 \mathrm{mg} / \mathrm{kg}$ dan $400 \mathrm{mg} / \mathrm{kg}$ asid sianurik (p.o., setiap hari selama tiga hari). Hasil kajian menunjukkan bahawa paras nitrogen darah urea meningkat dengan ketara dalam tikus yang dirawat dengan campuran melamina dan asid sianurik. Kadar aliran kencing, kadar penapisan glomerular, aliran plasma buah pinggang dan kencing natrium dan kadar perkumuhan kalium yang menurun dengan ketara jika dibandingkan dengan kawalan pengangkut. Keputusan ini menunjukkan glomeruli dan tubul buah pinggang tikus yang dirawat dengan campuran melamina dan asid sianurik telah rosak. Kajian histologi juga mengesahkan penemuan ini dan menunjukkan atrofi glomerul yang signifikan dan tubules buah pinggang mengalami dilatasi. Pelbagai kristal berwarna keperangan kuning ditemui dalam tubul distal, tubul pengumpulan dan salur papilari. Walau bagaimanapun, tikus yang dirawat dengan melamina sahaja menunjukkan tiada perbezaan yang signifikan dalam fungsi buah pinggang atau struktur.

Kata kunci: Asid sianurik; histologi; melamina; pembersihan renal; tikus

\section{INTRODUCTION}

Melamine $\left(\mathrm{C}_{3} \mathrm{H}_{6} \mathrm{~N}_{6}\right)$ is an important component for production of melamine resin, which is a combination of melamine and formaldehyde. Moreover, melamine has been used in agriculture to increase nitrogen levels in fertilizer. Melamine is also used as non-protein nitrogen for feeding ruminant animals in livestock. The hydrolytic reaction of melamine slowly occurs in ruminants (Newton \& Utley 1978). Recently, Sun et al. (2012) reported that melamine was gradually degraded into cyanuric acid by rumen microorganisms in lactating dairy cows (Sun et al. 2012). It seems that the addition of melamine is to increase nitrogen levels in fertilizer and animal food, consequently, measurement of protein levels is uncertain because many methods mainly estimate amount of nitrogen in the substrates (Dalal \& Goldfarb 2011; Hau et al. 2009; Vervaet et al. 2017).

An outbreak of melamine contamination in foods occurred throughout the world a decade ago. Wheat gluten containing melamine and cyanuric acid is added into animal foods in order to increase nitrogen levels (Hau et al. 2009). In rats, the inhalation of melamine can cause irritation of the respiratory tract, and the $\mathrm{LD}_{50}$ is $3.16 \mathrm{~g} / \mathrm{kg}$ body weight (p.o.) (Hau et al. 2009; National Toxicology Program 1983). Toxicity of melamine has been tested in Sprague-Dawley rats. Cyanuric acid is a structural analogue of melamine, which is toxic to mammals. Previous studies show that long-term exposure of cyanuric acid can cause bladder calculi and bladder epithelial hyperplasia in rats and mice. And, acute exposure of cyanuric acid results in 
slight eye and skin irritation in rabbits (Hammond et al. 1986; Suchy et al. 2009). Melamine-cyanuric acid complex damages the kidney leading to increase urination and blood urea nitrogen (BUN), and to decrease body weight and creatinine clearance. In addition, distal tubules and loop of Henle swell up, and crystals are found in the renal tubules, especially in the renal medulla. The crystals obstruct flow in the renal tubules. Analyses of crystals by HPLC-MS/ MS and Fourier transform infrared (FTIR) spectroscopy showed these crystals to be melamine cyanurate, which is an insoluble complex precipitating in renal tubules (Dobson et al. 2008). Furthermore, melamine cyanurate crystals were found in renal distal tubules of cats and dogs consuming melamine and cyanuric acid contaminated pet foods (Brown et al. 2007; Dalal \& Goldfarb 2011; Dobson et al. 2008; Puschner et al. 2007). Melamine cyanurate crystals cause bleeding of the corticomedullary junction and acute renal failure in cats with concentrated levels of melamine and cyanuric acid (496-734 mg/kg kidney weight and 487-690 mg/kg kidney weight, respectively) (Puschner et al. 2007). Moreover, melamine induces urinary bladder stones in rats and mice, however, bladder tumor did not develop in melamine-treated rodents (Melnick et al. 1984). Melamine and derivatives also affects the kidneys of Iberian piglets causing chronic inflammation. Crystal of melamine cyanurate are formed in dilated distal tubules and collecting ducts leading to a flattening of the renal tubular epithelial cells (Battaglia et al. 2010; González et al. 2009).

In economic aquatic animals, fish and shrimp fed with melamine-contaminated food were found to contain melamine in their tissue (Andersen et al. 2008). Cyanuric acid also accumulated in the tissue of trout, catfish, tilapia and shrimp (Karbiwnyk et al. 2009). Moreover, a mixture of melamine and cyanuric acid causes golden to greenish-brown needle- and plate-like crystals in multifocal hemocytic granulomas in the antennal gland tubules and peritubular hemal sinuses (Lightner et al. 2009).

The half-life of melamine in plasma of rhesus monkey given with a single dose of $1.4 \mathrm{mg}$ melamine $/ \mathrm{kg}$ body weight was $4.41 \pm 0.43 \mathrm{~h}$. Melamine was rapidly excreted through urination (Liu et al. 2010). Furthermore, derivatives of melamine, such as ammeline, ammelide and cyanuric acid are derived from deamination in Pseudomonas and Klebsiella (Jutzi et al. 1982).

The effect of melamine on renal functions including ion excretion is still limited. Here, we aimed to clarify the renal functions of Wistar rats consuming melamine and cyanuric acid using clearance technique and estimation of sodium and potassium excretion. In addition, kidney structure was observed and compared with that of control rats.

\section{MATERIALS AND METHODS}

ANIMALS

Male Wistar rats (200-250 g) were obtained from the Southern Laboratory Animal, Prince of Songkla University,
Songkhla, Thailand. All rats were reared under controlled conditions (temperature $23-25^{\circ} \mathrm{C}$, relative humidity $50-55 \%$ and $12 \mathrm{~h}$ light/dark cycle). They were given a commercial animal feed (S.W.T., Thailand) and free access to tap water. All experimental rats were maintained and handled according to the approval of the Prince of Songkla University Animal Ethics Committee (project license number: MOE 0521.11/143).

\section{EXPERIMENTAL DESIGN}

Animals were randomly assigned to three groups (vehicle control, melamine and melamine + cyanuric acid). The number of animal in each group was six. Melamine (Sigma, Wisconsin, USA) at a dose of $400 \mathrm{mg} / \mathrm{kg}$ body weight or cyanuric acid (Sigma, Tokyo, Japan) at a dose of $400 \mathrm{mg} / \mathrm{kg}$ body weight was dissolved in $1 \%$ carboxymethylcellulose (vehicle) and orally administered once a day for three days. An equal volume of $5 \mathrm{~mL} / \mathrm{kg}$ body weight was administered to each animal in all groups.

\section{RENAL CLEARANCE STUDY}

Rats were anaesthetized (i.p) with $60 \mathrm{mg} / \mathrm{kg}$ body weight of Nembutal (pentobarbitone sodium; Ceva Sante Animale, Libourne, France) and placed on a thermostatically controlled heated table to maintain body temperature at $37^{\circ} \mathrm{C}$. A tracheostomy was performed and the right carotid artery was cannulated for blood sampling and arterial blood pressure recording (Grass Polygraph model 7DAG; Grass Instrument Co., Quincy, MA, USA) throughout the experiment. The left jugular vein was then cannulated and infused with $0.9 \% \mathrm{NaCl}$ containing $1 \%$ inulin and $0.5 \%$ para-aminohippuric acid (PAH) at the rate of $1.6 \mathrm{~mL} / \mathrm{h} / 100 \mathrm{~g}$ body weight. Urine samples were collected in microcentrifuge tubes through a cannula placed in the bladder via a suprapubic midline incision. A one-hour equilibration period was allowed in order to obtain a steady state of plasma inulin and PAH concentration before clearance measurement were undertaken.

After the equilibration period, all rats were subjected to an identical protocol in which six consecutive $30 \mathrm{~min}$ urine collections were made. Three arterial blood samples $(500 \mu \mathrm{L})$ were taken at the mid-point of the first, fourth and sixth urine samples. Whole blood samples were centrifuged, then plasma was collected and frozen stored until determining of concentration of clearance markers, electrolytes and BUN. Blood cells were resuspended in $300 \mu \mathrm{L}$ isotonic saline and returned to the animal via the jugular vein cannula. At the end of the renal clearance experiment, animals were euthanized and both kidneys were removed, blotted, weighed and then fixed in $10 \%$ buffer neutral formalin for histopathological examination.

Renal clearance of PAH and inulin were calculated according to the clearance equation and were taken as the indices of renal plasma flow (RPF) and glomerular filtration rate (GFR), respectively. RPF was calculated 
assuming a $90 \%$ extraction of PAH. Inulin and PAH concentrations were estimated by spectrophotometric method (Davidson \& Sackner 1963; Smith et al. 1945). Urine output was determined gravimetrically assuming a density of $1 \mathrm{~g} / \mathrm{mL}$. $\mathrm{Na}^{+}$and $\mathrm{K}^{+}$concentration was measured by an inductively coupled plasma-optical emission spectrophotometer (Optima 4300 DV, Perkin Elmer, MA, USA) using $\mathrm{NaCl}$ and $\mathrm{KCl}$ as their standard solutions, respectively. Fractional excretion of $\mathrm{Na}^{+}\left(\mathrm{FE}_{\mathrm{Na}}\right)$ and $\mathrm{K}^{+}\left(\mathrm{FE}_{\mathrm{K}}\right)$ was calculated according to the equation: $\mathrm{FE}_{\mathrm{x}}=\left(\mathrm{C}_{\mathrm{x}} / \mathrm{GFR}\right) \times 100$, where $\mathrm{FE}_{\mathrm{x}}$ is fractional excretion of $\mathrm{Na}^{+}$and $\mathrm{K}^{+}, \mathrm{C}_{\mathrm{x}}$ is clearance of $\mathrm{Na}^{+}$and $\mathrm{K}^{+}$.

BUN level was estimated by enzymatic method using urease enzyme kit (Humana, Wiesbaden, Germany).

\section{RENAL HISTOPATHOLOGICAL EXAMINATION}

The kidney samples were fixed in $10 \%$ buffered neutral formalin for at least $24 \mathrm{~h}$, then dehydrated in a series of graded concentrations of ethanol and embedded in paraffin wax (Tyco/Healthcare, Manfield, USA). The tissue block was cut into $6 \mu \mathrm{m}$-thick sections using rotary microtome (model 820, Tucson, AZ, USA). Paraffin sections were stained with hematoxylin and eosin for light microscope examination. The sections were viewed and photographed on a light microscope (Olympus BX51, Tokyo, Japan) with attachment camera (Olympus DP 50, Olympus Optical Co. Ltd. Japan). Ten sections were prepared from each kidney. All sections were evaluated for glomerular atrophy and tubular dilatation. To evaluate for glomerular atrophy, total glomeruli and atrophic glomeruli were counted in 10 fields using eyepiece micrometer grid under $400 \times$ magnifications. To evaluate for tubular dilatation, diameters of proximal tubules, distal tubules and papillary ducts were measured in 10 fields using eyepiece micrometer grid under $400 \times$ magnifications.

\section{STATISTICAL ANALYSIS}

All experimental data are presented as mean \pm standard error of mean (S.E.M.) from at least 6 sets of experiments. Statistical difference was assessed using One-way analysis of variance (ANOVA) with Student Newman-Keuls Posthoc test, and $p<0.05$ was considered to be statistically significant.

\section{RESULTS}

\section{BODY WEIGHT CHANGE}

The pre-treatment body weight, post-treatment body weight and body weight change are shown in Table 1 . After treatment with melamine+cyanuric acid, the body weight $(-12.0 \pm 4.7 \mathrm{~g})$ was significantly reduced, which was different from vehicle control $(5.7 \pm 3.0 \mathrm{~g})$ and melamine groups $(9.7 \pm 2.7 \mathrm{~g})$.

\section{RENAL CLEARANCE EXPERIMENT}

During the clearance experiment, mean arterial blood pressure (MABP) showed the significantly difference among all three groups (vehicle control $=128 \pm 1 \mathrm{~mm}$ $\mathrm{Hg}$, melamine $=119 \pm 4 \mathrm{~mm} \mathrm{Hg}$ and melamine + cyanuric acid $=115 \pm 8 \mathrm{~mm} \mathrm{Hg}$ ).

The urine flow rate, GFR and RPF of melamine+cyanuric acid-treated rats were significantly decreased when compared with vehicle control and melamine treated group (Figure 1(A), 1(B) and 1(C)). Urine flow rate in melamine+cyanuric acid-treated group decreased to $73 \%$ compared with control. The GFR decreased to $0.352 \pm$ $0.211 \mathrm{~mL} / \mathrm{min} / \mathrm{g}$ kidney weight (melamine+cyanuric acid), while GFR of vehicle control and melamine-treated group were $1.504 \pm 0.100,1.339 \pm 0.062 \mathrm{~mL} / \mathrm{min} / \mathrm{g}$ kidney weight, respectively. The RPF of vehicle control, melamine and melamine+cyanuric acid-treated groups were $5.07 \pm 0.317,3.889 \pm 0.351$ and $0.951 \pm 0.602$ $\mathrm{mL} / \mathrm{min} / \mathrm{g}$ kidney weight, respectively. As indicated in Figure 1(D), BUN significantly increased after treatment with melamine+cyanuric acid $(230.258 \pm 72.598 \mathrm{mg} / \mathrm{dl})$ when compared with vehicle control $(16.185 \pm 0.903$ $\mathrm{mg} / \mathrm{dl})$ and melamine-treated groups (14.049 \pm 0.662 $\mathrm{mg} / \mathrm{dl})$. However, the urine flow rate, GFR, RPF and BUN of melamine-treated rats were not different from vehicle control (Figure 1).

Figure 2(A) shows a significant decrease in $\mathrm{Na}^{+}$ excretion rate in the melamine+cyanuric acid-treated group $(1.226 \pm 0.683 \mu \mathrm{mol} / \mathrm{min} / \mathrm{g}$ kidney weight compared with the vehicle control and melamine-treated groups $(5.236 \pm 0.261 \mu \mathrm{mol} / \mathrm{min} / \mathrm{g}$ kidney weight and $5.119 \pm 0.435 \mu \mathrm{mol} / \mathrm{min} / \mathrm{g}$ kidney weight, respectively). The melamine+cyanuric acid group also showed

TABLE 1. Effect of melamine and melamine+cyanuric acid treated on pre-treatment body weight, post-treatment body weight and body weight change

\begin{tabular}{lccr}
\hline Groups & $\begin{array}{c}\text { Pre-treatment } \\
\text { body weight }(\mathrm{g})\end{array}$ & $\begin{array}{c}\text { Post-treatment } \\
\text { body weight }(\mathrm{g})\end{array}$ & $\begin{array}{c}\text { Body weight } \\
\text { change }(\mathrm{g})\end{array}$ \\
\hline Vehicle control $(n=6)$ & $244.0 \pm 5.2$ & $249.7 \pm 3.9$ & $5.7 \pm 3.0$ \\
Melamine $(n=6)$ & $220.0 \pm 11.9$ & $229.7 \pm 12.6$ & $9.7 \pm 2.7$ \\
Melamine+Cyanuric acid $(n=6)$ & $205.2 \pm 12.0$ & $193.2 \pm 15.0^{*, \dagger}$ & $-12.0 \pm 4.7^{*}, \dagger$ \\
\hline
\end{tabular}

Data are mean \pm S.E.M. * $\uparrow$ † $<0.05$ compared with vehicle control and melamine group, respectively 


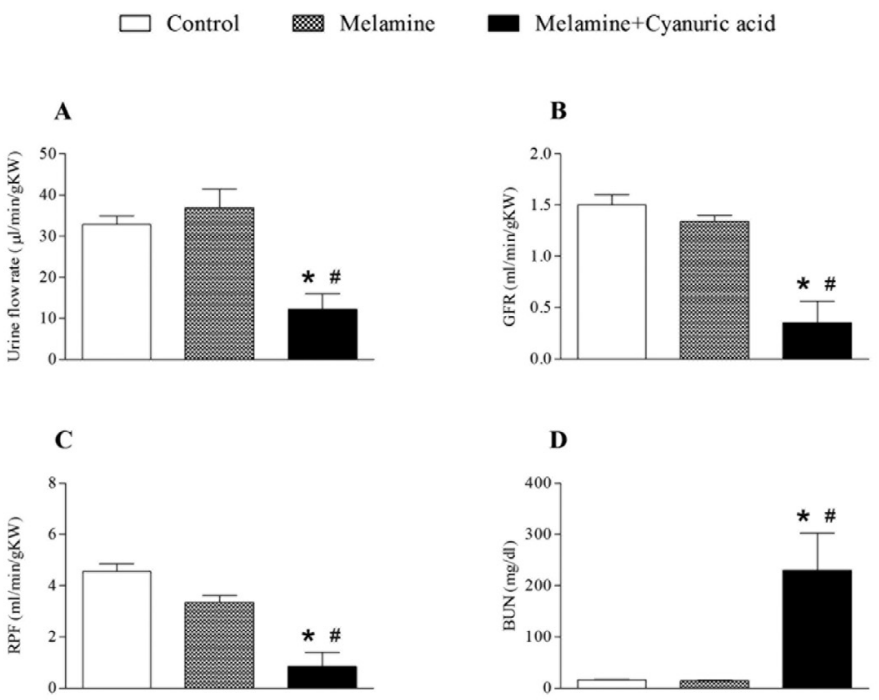

FIGURE 1. Effect of melamine+cyanuric acid on urine flow rate, glomerular filtration rate (GFR), renal plasma flow (RPF) and blood urea nitrogen (BUN). Values are mean \pm S.E.M. from at least 6 sets of experiments. $*, \dagger p<0.05$ compared to vehicle control and melamine group, respectively (one-way ANOVA with multiple comparison using Student-Newman Keuls post hoc test)

significantly decreased $\mathrm{K}^{+}$excretion rate $(0.59 \pm 0.180$ $\mu \mathrm{mol} / \mathrm{min} / \mathrm{g}$ kidney weight) when compared with vehicle control and melamine treated groups $(1.879 \pm 0.111$ $\mu \mathrm{mol} / \mathrm{min} / \mathrm{g}$ kidney weight and $1.692 \pm 0.119 \mu \mathrm{mol} / \mathrm{min} / \mathrm{g}$ kidney weight, respectively) (Figure 2(B)). Consequently, $\mathrm{FE}_{\mathrm{Na}}$ of rats treated with melamine+cyanuric acid was significantly increased to $9.636 \pm 3.422 \%$ compared with vehicle control $(2.403 \pm 0.170 \%)$ and melamine-treated rats $(2.749 \pm 0.157 \%)$ (Figure $2(\mathrm{C})$ ). Moreover, treatment with melamine + cyanuric acid resulted in a significantly increased $\mathrm{FE}_{\mathrm{K}}(84.105 \pm 26.836 \%$ ), which was higher than that of vehicle control and melamine groups (10.126 \pm $1.152 \%$ and $12.734 \pm 10.790 \%$ ) (Figure 2(D)).

\section{RENAL HISTOPATHOLOGICAL STUDY}

Kidney weight of melamine+cyanuric acid-treated rats was significantly higher than that of vehicle control and melamine-treated rats as shown in Table 2. Melamine treatment alone did not affect kidney weight, when compared with vehicle control (Table 2).

Structural alterations of glomerulus, renal tubule appeared in both proximal tubule and distal tubule of rats

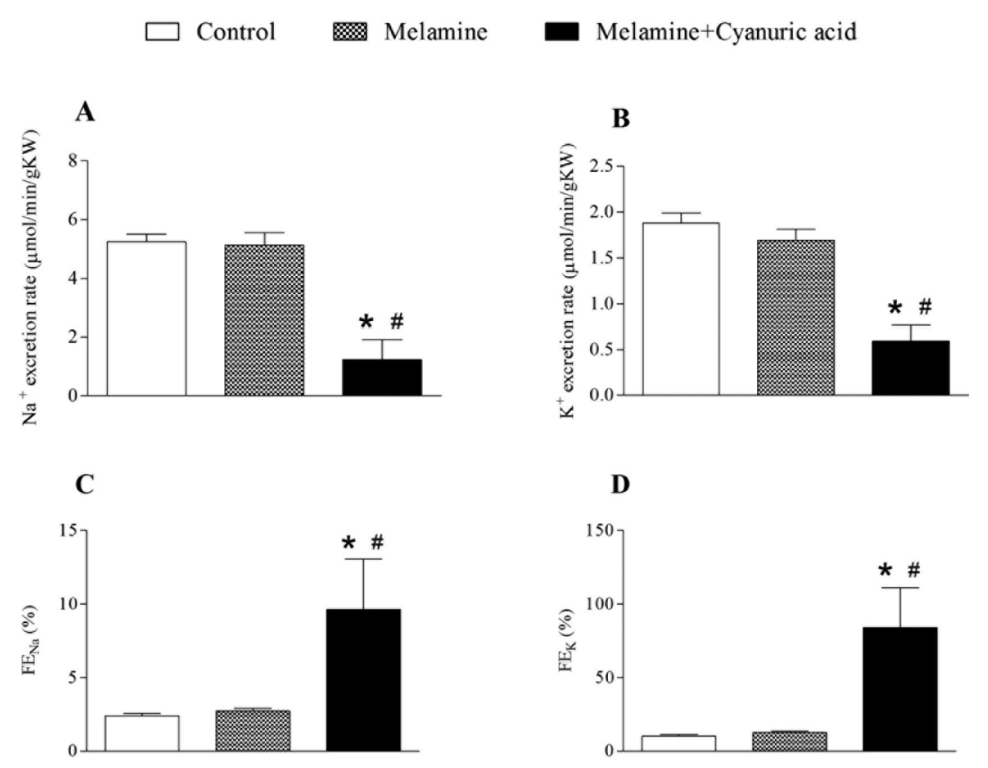

FIGURE 2. Effect of melamine+cyanuric acid on $\mathrm{Na}^{+}$excretion rate, $\mathrm{K}^{+}$excretion rate, fractional excretion of sodium $\left(\mathrm{FE}_{\mathrm{Na}}\right)$ and potassium $\left(\mathrm{FE}_{\mathrm{K}}\right)$. Values are mean \pm S.E.M. from at least 6 sets of experiments. ${ }^{*}, \# p<0.05$ compared to vehicle control and melamine group, respectively (one-way ANOVA with multiple comparison using Student-Newman Keuls post hoc test) 
TABLE 2. Effect of melamine and melamine+cyanuric acid treated on kidney weight

\begin{tabular}{lc}
\hline Groups & Kidney weight $/ 100 \mathrm{~g} \mathrm{BW}(\mathrm{g})$ \\
\hline Vehicle control $(n=6)$ & $0.637 \pm 0.012$ \\
Melamine $(n=6)$ & $0.719 \pm 0.025$ \\
Melamine+Cyanuric acid $(n=6)$ & $1.539 \pm 0.206^{*, \dagger}$ \\
\hline
\end{tabular}

Data are mean \pm S.E.M. $*, \dagger p<0.05$ compared with vehicle control and melamine group, respectively

treated with melamine+cyanuric acid are shown in Figure 3. Bowman's space and glomerular capillary atrophy were found in kidney of rats after melamine+cyanuric acid treatment (Figure 3(E)). The glomerular atrophy in kidney of melamine+cyanuric acid group $(44.13 \pm 12.45 \%)$ was higher than that in vehicle control and melamine groups ( $7.03 \pm 0.88 \%$ and $12.44 \pm 1.40 \%$, respectively) (Table 3 ). Moreover, tubular dilatation and brownish-yellow crystals were found in kidneys of melamine+cyanuric acid treated rats. The lumina of proximal tubules, distal tubules, and papillary ducts were dilated in the melamine+cyanuric acid-treated group when compared with vehicle control and melamine treated groups. The crystals found in kidney tissue seemed to obstruct the renal tubules (Table 4 and Figure 3(E) and Figure 3(F)).

\section{DISCUSSION}

To investigate the effects of melamine on renal functions, rats were gavaged melamine and melamine+cyanuric acid mixture for 3 days. The results showed that body weight of rats receiving the mixture was significantly decreased, when compared with control and melamine-treated rats. Moreover, hematuria was found in some rats treated with melamine+cyanuric acid mixture and this is consistent with previous study (Dobson et al. 2008; Gamboa et al. 2012).

In this study, we performed renal clearance to evaluate kidney function of rats received melamine, and mixture of melamine and cyanuric acid. The results showed that GFR and RPF in the mixture group were significantly lower than in control and melamine groups. Previously,
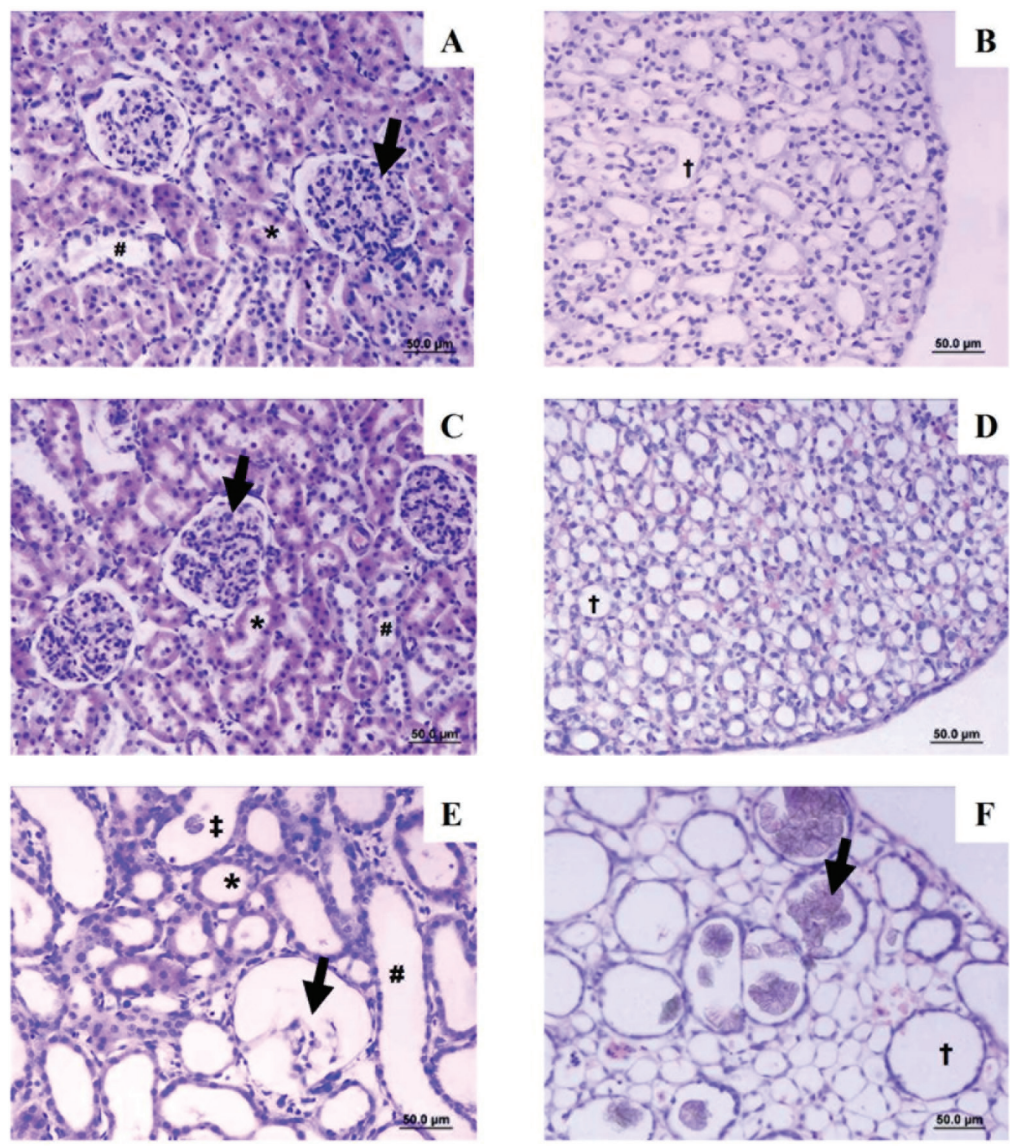

FIGURE 3. Light micrograph of glomerulus (black arrow), proximal tubule (*), distal tubule (\#) and papillary duct $(\dagger)$ in vehicle control (A\&B), melamine treated (C\&D) and melamine+cyanuric acid treated group (E\&F). In melamine+cyanuric acid group, glomerular atrophy, renal tubular dilatation and crystal ( $\$)$ were observed. Hematoxylin \& eosin stain. Scale bar $=50 \mu \mathrm{m}$ 
TABLE 3. Histopathological scoring of glomerular atrophy in vehicle control, melamine and melamine+cyanuric acid treated-rats

\begin{tabular}{lc}
\hline Groups & Glomerular atrophy $(\%)$ \\
\hline Vehicle control $(n=6)$ & $7.03 \pm 0.88$ \\
Melamine $(n=6)$ & $12.44 \pm 1.40$ \\
Melamine+Cyanuric acid $(n=6)$ & $44.13 \pm 12.45 * ;$ \\
\hline Data are mean \pm S.E.M. $*, \dagger p<0.05$ compared with vehicle control and melamine group, respectively
\end{tabular}

TABLE 4. Effect of melamine and melamine+cyanuric acid treated on the size of proximal tubule, distal tubule and papillary duct

\begin{tabular}{lccc}
\hline Groups & $\begin{array}{c}\text { Proximal tubule } \\
(\mu \mathrm{m})\end{array}$ & $\begin{array}{c}\text { Distal tubule } \\
(\mu \mathrm{m})\end{array}$ & $\begin{array}{c}\text { Papillary duct } \\
(\mu \mathrm{m})\end{array}$ \\
\hline Vehicle control $(n=6)$ & $40.1 \pm 0.9$ & $37.5 \pm 1.4$ & $36.8 \pm 2.6$ \\
Melamine $(n=6)$ & $39.1 \pm 0.7$ & $38.3 \pm 1.2$ & $37.7 \pm 2.6$ \\
Melamine+Cyanuric acid $(n=6)$ & $44.6 \pm 1.4^{*, \dagger}$ & $49.4 \pm 4.7^{*, \dagger}$ & $55.6 \pm 6.9^{*, \dagger}$ \\
\hline
\end{tabular}

Data are mean \pm S.E.M. $*, \dagger p<0.05$ compared with vehicle control and melamine group, respectively

a mixture of melamine and melamine derivatives was able to decrease creatinine clearance and renal blood flow in cats and Sprague-Dawley rats (Dobson et al. 2008; Puschner et al. 2007; Tian et al. 2016). We also observed the kidney structures including glomerulus and renal tubules, showing glomerulus atrophy in rats given the mixture of melamine and cyanuric acid. Furthermore, yellowish crystals were found in distal tubules, collecting tubules and papillary duct, and these have been reported to cause renal failure (Brown et al. 2007; Dobson et al. 2008; González et al. 2009; Puschner et al. 2007). Previous studies also reported that administration of high dose of melamine $(1000 \mathrm{mg} / \mathrm{kg}$ body weight $)$ into pregnant and non-pregnant rats caused crystal formation and induced renal failure, which stimulated reproductive abnormality and increased numbers of early and late fetal deaths (Stine et al. 2014; Tian et al. 2016). Melamine also induces renal inflammation and fibrosis (Tian et al. 2016).

The crystals were formed in distal tubules because of the reabsorption of water and minerals in proximal tubules leading to increased concentration of melamine cyanurate. Consequently, highly concentrated melamine cyanurate crystalized and was precipitated in the distal tubules, collecting ducts and papillary ducts, which was consistent with previous study in cats, dogs and piglets (Brown et al. 2007; González et al. 2009; Puschner et al. 2007). These crystals obstructed and caused increased hydrostatic pressure in renal tubules, which led to destruction of the glomeruli and decreased GFR, sodium excretion rate, and potassium excretion rate. Moreover, fractional sodium and potassium excretion were increased in rats receiving melamine and cyanuric acid, because the epithelial cells of renal tubules were flattened. This leads to a decreased reabsorption of $\mathrm{Na}^{+}$and $\mathrm{K}^{+}$in renal tubules, especially distal tubules, collecting ducts and papillary ducts of animals, similar to the findings in Iberian piglets (González et al. 2009).
Furthermore, plasma BUN significantly increased because of body weight loss and energy compensation. Protein is utilized as an energy source, and deamination produces high levels of ammonia. Ammonia would be converted to urea in the liver, which is normally filtered at the glomerulus (Nelson \& Cox 2013). In this study, glomeruli were shrunken, therefore, urea could not pass through glomerulus and caused higher level of BUN in plasma (González et al. 2009; Park et al. 2011; Puschner et al. 2007; Son et al. 2014). Recent study also showed that urinary biomarkers (calbindin, NGAL and KIM-1) were increased in Sprague-Dawley rats treated with mixture of melamine and cyanuric acid indicating that nephrotoxicity occurred in kidneys of rats (Son et al. 2014).

\section{CONCLUSION}

This study showed the structural and functional effects of melamine and cyanuric acid crystalized in rat kidney including ion excretion rates of renal failure rats. Crystals of melamine cyanurate obstructed in renal tubules, which caused dilation of renal tubules and glomerular atrophy. The structural changes of rat kidneys also affect to renal function and caused decreasing of GFR and RPF, and increasing of BUN and excretion rate of $\mathrm{Na}^{+}$and $\mathrm{K}^{+}$. These findings should be useful to improve treatment methods in the future. However, the treatment and protection against crystallization in the kidney should be investigated the further experiments.

\section{ACKNOWLEDGEMENTS}

We would like to thank Asst. Prof. Kanoktorn Piyathamrongrut for her advice in histology, the Department of Biology, Faculty of Science, Prince of Songkla University, and Development and Promotion of Science and Technology Talents Project (DPST) for the financial 
supports. We would also like to thank Dr. Alan Frederick - Geater for English proofreading this manuscript.

\section{REFERENCES}

Andersen, W.C., Turnipseed, S.B., Karbiwnyk, C.M., Clark, S.B., Madson, M.R., Gieseker, C.M., Miller, R.A., Rummel, N.G. \& Reimschuessel, R. 2008. Determination and confirmation of melamine residues in catfish, trout, tilapia, salmon, and shrimp by liquid chromatography with tandem mass spectrometry. J. Agric. Food Chem. 56: 4340-4347.

Battaglia, M., Cruywagen, C.W., Bertuzzi, T., Gallo, A., Moschini, M., Piva, G. \& Masoero, F. 2010. Transfer of melamine from feed to milk and from milk to cheese and whey in lactating dairy cows fed single oral doses. J. Dairy Sci. 93: 5338-5347.

Brown, C.A., Jeong, K.S., Poppenga, R.H., Puschner, B., Miller, D.M., Ellis, A.E., Kang, K., Sum, S., Cistola, A.M. \& Brown, S.A. 2007. Outbreaks of renal failure associated with melamine and cyanuric acid in dogs and cats in 2004 and 2007. J. Vet. Diagn. Invest. 19: 525-531.

Dalal, R.P. \& Goldfarb, D.S. 2011. Melamine-related kidney stones and renal toxicity. Nat. Rev. Nephrol. 7: 267-274.

Davidson, W.D. \& Sackner, M.A. 1963. Simplification of the anthrone method for the determination of inulin in clearance studies. J. Lab. Clin. Med. 62: 351-356.

Dobson, R.L.M., Motlagh, S., Quijano, M., Cambron, R.T., Baker, T.R., Pullen, A.M., Regg, B.T., Bigalow-Kern, A.S., Vennard, T., Fix, A., Reimschuessel, R., Overmann, G., Shan, Y. \& Daston, G.P. 2008. Identification and characterization of toxicity of contaminants in pet food leading to an outbreak of renal toxicity in cats and dogs. Toxicol. Sci. 106: 251-262.

Gamboa, G., Jacob, C.C., Von Tungeln, L.S., Hasbrouck, N.R., Olson, G.R., Hattan, D.G., Reimschuessel, R. \& Beland, F.A. 2012. Dose - Response assessment of nephrotoxicity from a twenty-eight-day combined-exposure to melamine and cyanuric acid in F344 rats. Toxicol. Appl. Pharmacol. 262: 99-106.

González, J., Puschner, B., Pérez, V., Ferreras, M.C., Delgado, L., Muñoz, M., Pérez, C., Reyes, L.E., Velasco, J., Fernández, V. \& García-Marín, J.F. 2009. Nephrotoxicosis in Iberian piglets subsequent to exposure to melamine and derivatives in Spain between 2003 and 2006. J. Vet. Diagnostic Investig. 21: 558-563.

Hammond, B.G., Barbee, S.J., Inoue, T., Ishida, N., Levinskas, G.J., Stevens, M.W., Wheeler, A.G. \& Cascieri, T. 1986. A review of toxicology studies on cyanurate and its chlorinated derivatives. Environ. Health Perspect. 69: 287-292.

Hau, A.K., Kwan, T.H. \& Li, P.K. 2009. Melamine toxicity and the kidney. J. Am. Soc. Nephrol. 20: 245-250.

Jutzi, K.,Cook,A.M. \& Hütter, R. 1982. The degradative pathway of the s-triazine melamine: The steps to ring cleavage. Biochem.J. 208: 679-684.

Karbiwnyk, C.M.,Andersen, W.C., Turnipseed, S.B., Storey, J.M., Madson, M.R., Miller, K.E., Gieseker, C.M., Miller, R.A., Rummel, N.G. \& Reimschuessel, R. 2009. Determination of cyanuric acid residues in catfish, trout, tilapia, salmon and shrimp by liquid chromatography-tandem mass spectrometry. Anal. Chim. Acta. 637: 101-111.

Lightner, D.V., Pantoja, C.R., Redman, R.M., Hasson, K.W. \& Menon, J.P. 2009. Case reports of melamine-induced pathology in penaeid shrimp fed adulterated feeds. Dis. Aquat. Organ. 86: 107-112.
Liu, G., Li, S., Jia, J., Yu, C., He, J., Yu, C. \& Zhu, J. 2010 Pharmacokinetic study of melamine in rhesus monkey after a single oral administration of a tolerable daily intake dose. Regul. Toxicol. Pharmacol. 56: 193-196.

Melnick, R.L., Boorman, G.A., Haseman, J.K., Montali, R.J. \& Huff, J. 1984. Urolithiasis and bladder carcinogenicity of melamine in rodents. Toxicol. Appl. Pharmacol. 72: 292-303.

National Toxicology Program. 1983. NTP Carcinogenesis bioassay of melamine (CAS No. 108-78-1) in F344/N Rats and B6C3FMice (Feed Study). Natl. Toxicol. Progr. Tech. Rep.Ser. 245: 1-171.

Nelson, D.L. \& Cox, M.M. 2013. Lehninger Principles of Biochemistry. New York- Basingstoke: FreemanMacmillan.

Newton, G.L. \& Utley, P.R. 1978. Melamine as a dietary nitrogen source for ruminants. J. Anim. Sci. 47: 1338-1344.

Park, D., Kim, T.K., Choi, Y.J., Lee, S.H., Bae, D.K., Yang, G., Yang, Y.H., Joo, S.S., Choi, E.K., Ahn, B., Kim, J.C., Kim, K.S. \& Kim, Y.B. 2011. Increased nephrotoxicity after combined administration of melamine and cyanuric acid in rats. Lab. Anim. Res. 27: 25-28.

Puschner, B., Poppenga, R.H., Lowenstine, L.J., Filigenzi, M.S. \& Pesavento, P.A. 2007. Asessment of melamine and cyanuric acid toxicity in cats. J. Vet. Diagn. Invest. 19: 616-624.

Smith, H.W., Finkelstein, N., Aliminosa, L., Crawford, B. \& Graber, M. 1945. The renal clearances of substituted hipppuric acid derivatives and other aromatic acids in dog and man. J. Clin. Invest. 24: 388-404.

Son, J.Y., Kang, Y.J., Kim, K.S., Kim, T.H., Lim, S.K., Lim, H.J., Jeong, T.C., Choi, D.W., Chung, K.H., Lee, B.M. \& Kim, H.S. 2014. Evaluation of renal toxicity by combination exposure to melamine and cyanuric acid in male SpragueDawley rats. Toxicol. Res. 30: 99-107.

Stine, C.B., Reimschuessel, R., Keltner, Z., Nochetto, C.B., Black, T., Olejnik, N., Scott, M., Bandele, O., Nemser, S.M., Tkachenko, A., Evans, E.R., Crosby, T.C., Ceric, O., Ferguson, M., Yakes, B.J. \& Sprando, R. 2014. Reproductive toxicity in rats with crystal nephropathy following high doses of oral melamine or cyanuric acid. Food Chem. Toxicol. 68: 142-153.

Suchy, P., Strakova, E., Herzig, I., Stana, J., Kalusova, R. \& Pospichalova, M. 2009. Toxicological risk of melamine and cyanuric acid in food and feed. Interdiscip.Toxicol. 2: 55-59.

Sun, P., Wang, J.Q., Shen, J.S. \& Wei, H.Y. 2012. Pathway for the elimination of melamine in lactating dairy cows. $J$. Dairy Sci. 95: 266-271.

Tian, X.Y., Wong, W.T., Lau, C.W., Wang, Y., Cheang, W.S., Liu, J., Lu, Y., Huang, H., Xia, Y., Chen, Z.Y., Mok, C.S., Lau, C.M. \& Huang, Y. 2016. Melamine impairs renal and vascular function in rats. Sci. Rep. 6: 28041.

Vervaet, B.A.,D'Haese, P.C. \& Verhulst,A. 2017. Environmental toxin-induced acute kidney injury. Clin. Kidney J. 10: 747 758.

Saranya Peerakietkhajorn*

Department of Biology

Faculty of Science

Prince of Songkla University

Hat yai, Songkhla, 90110

Thailand 
Nawiya Huipao \& Siriphun Hiranyachattada Department of Physiology

Faculty of Science

Prince of Songkla University

Hat yai, Songkhla, 90110

Thailand

Siriphun Hiranyachattada

School of Pharmacy

Walailak University

Thasala, Nakornsrithammart, 80160

Thailand
*Corresponding author; email: saranya.pe@psu.ac.th

Received: 3 February 2019

Accepted: 18 May 2019 